УДК 681.620(042.3)

\title{
ДОСЛІДЖЕННЯ ТОЧНОСТІ ПОЗИЦІОНУВАННЯ ТРАНСПОРТУВАЛЬНИХ ПРИСТРОЇВ КОНВЕЕРНОГО ТИПУ ТАМПОДРУКАРСЬКОї МАШИНИ ТДМ-300
}

\author{
○ Ю. О. Шостачук, К.Т.н., доцент, Д. С. Гриценко, \\ аспірант, НТУУ «КП|», Київ, Україна \\ В статье рассматриваются результаты исследования
точности позиционирования изделий при транспор-
тировании их в зону печати в тампопечатных машинах. \\ In article it is considered results of research accuracy \\ positioning of products at their transportation to a press \\ zone in pad printing machines.
}

\section{Постановка проблеми}

Якість відтворення зображення у тамподрукарських машинах залежить від точності нанесення на виріб шару фарби. Нанесення фарбового зображення на вироби у тамподрукарських машинах залежить від взаємодії тампона i, відповідно, його механізму приводу та положення поданого у зону нанесення фарби виробу, який розташований на транспортувальному пристрою. Цей процес потребує забезпечення чіткої взаємодії всіх причетних до цього елементів друкарської машини.

Під час подачі виробів у зону друкування необхідно забезпечити їх плавну зупинку без додаткових вібрацій і коливань та чітку фіксацію відносно друкарського елементу. Вплив вібрацій та коливань приводить до порушення точності розміщення виробу відносного тампону і унеможливлює точне нанесення фарби на виріб. Гарантування відповідної якості друкування ускладнюється тим, що вико- навчі елементи, від яких залежить необхідна точність взаємодії, розташовані на різних механізмах.

\section{Аналіз попередніх досліджень}

Процес нанесення фарби на виріб виконується у період вистою транспортувального пристрою, що є особливістю процесу друку у ТДМ. Тому пристрої, які переносять виріб у зону друкування i, які $\epsilon$ опорною поверхнею для створення необхідного тиску під час нанесення фарби, повинні забезпечити плавний рух транспортера, задане співвідношення періодів руху та вистою згідно технологічного процесу, відповідну точність позиціонування виробу і його фіксацію відносно друкарського елемента (тампона) [1].

Точність позиціонування механізму - це якість відтворення встановлених залежностей ідеального механізму реальними системами. Ці залежності ха- 
рактеризуються зв'язком координат ведених та ведучих ланок механізмів.

Визначення точності механізму - визначення придатності реального механізму виконувати задані функцій на протязі заданого проміжку часу.

Реальний механізм відрізняється від відповідного ідеального похибками, що виникають внаслідок спрощення схем механізмів та залежностей при відтворенні руху, внаслідок похибок при виготовленні і монтажу, а також зміни характеристик внаслідок експлуатації обладнання. Найчастіше вводяться спрощення в закони руху механізму (наприклад: заміна нелінійної залежності лінійною при незначних відхиленнях від лінійності). Похибки механізмів, які виникають від таких спрощень, іноді називають теоретичними, структурними або схемними, вони завжди мають систематичний характер.

Найбільш поширеними похибками механізмів є виробничі (технологічні) похибки - будьякі відхилення в розмірах і формі деталей від теоретичних (номінальних), а також похибки взаємного розташування деталей, які виникають під час складання. Ці виробничі похибки носять назву первинних похибок механізму [1, 2].

Первинні похибки характеризуються величиною і напрямом. Якщо напрям певний, то первинні похибки називають векторними. При невизначному напрямі (не співвісність, ексцентриситети, перекоси осей шарнірів тощо) первинні похибки називають скалярними. У розрахунках на точність для скалярних первинних похибок враховують тільки їх величину, для векторних - величину і напрям.

Положення веденої ланки ідеального механізму характеризується рівнянням:

$$
\varphi_{0}=\varphi_{0}\left(q_{\mathrm{s}}\right),
$$

де $\mathrm{q}_{\mathrm{s}}$ - задані незалежні між собою параметри, що визначають положення виконавчих ланок. Параметри $\mathrm{q}_{\mathrm{s}}$ реального механізму відрізняються від ідеальних на величини похибок $\Delta \mathrm{q}_{\mathrm{s}}$. Тоді залежність (1) перетворюється на:

$$
\varphi=\varphi\left(q_{\mathrm{s}}+\Delta \mathrm{q}_{\mathrm{s}}\right),
$$

де $\Delta \mathrm{q}_{\mathrm{s}}$ - первинні похибки.

Різниця між положенням peального і ідеального механізмів і є похибкою положення веденої ланки механізму:

$$
\Delta \varphi=\varphi-\varphi_{0} .
$$

Похибка положення виконавчої ланки механізмів спричиняє додаткові переміщення ланок і зміну реальних швидкостей і прискорень веденої ланки. Похибки прискорень є причиною додаткових сил інерції, які змінюють реакцій в кінематичних парах, викликають додаткові вібрації у вузлах і суттєво погіршують точність позиціонування виконавчих ланок механізму.

У масовому виробництві усі первинні похибки мають випадковий характер, тому аналіз їх впливу необхідно виконувати з використанням теорії ймовірності розсіювання параметрів.

Крім перелічених похибок (відхилень) технологічного походження, на точність механізмів впли- 
вають також експлуатаційні, які виникають у процесі роботи механізмів. До них належать насамперед похибки, зумовлені зазорами в кінематичних парах механізмів, а також їх спрацюванням. Якщо величини технологічних зазорів нормуються стандартними допусками, то величини допустимих зазорів внаслідок спрацювання кінематичних пар, визначаються тільки розрахунками точності механізмів.

До експлуатаційних похибок належать також деформації деталей від сил тяжіння, технологічних сил, сил тертя тощо. Деформації деталей внаслідок дії додаткових сил призводять до появи мертвих ходів механізму, додаткових коливань і вібрацій, що спотворює розрахункову точність положення механізму.

Похибки механізму можуть бути зумовлені також шорсткістю і хвилястістю поверхонь, неправильними величинами і розподілом мас ланок, неправиль- ними величинами, напрямами і точками прикладання сил, відхиленнями в показниках пружних властивостей ланок [3].

\section{Мета роботи}

Метою даної роботи є аналіз процесу нанесення фарби на виріб у тамподрукарських машинах і визначення основних параметрів транспортувальної системи для забезпечення встановленої якості друку.

\section{Результати проведених досліджень}

На рис. 1 представлена структурна схема транспортної системи тамподрукарської машини з кроковим приводом, що складається $з$ кулачкового приводного механізму 1 , ланцюгової передачі 2, натяжного механізму 3, напрямних 4 та опорних пластин 5.

3 представленої схеми видно, що основними елементами, від яких залежить точність позиціонування закріплених на опор-

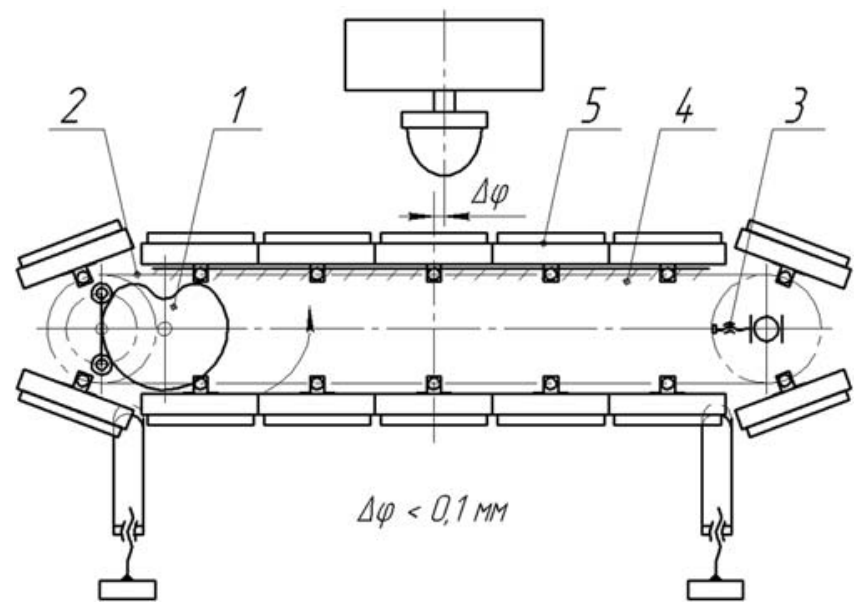

Рис. 1. Структурна схема приводу крокового транспортера тамподрукарської машини 

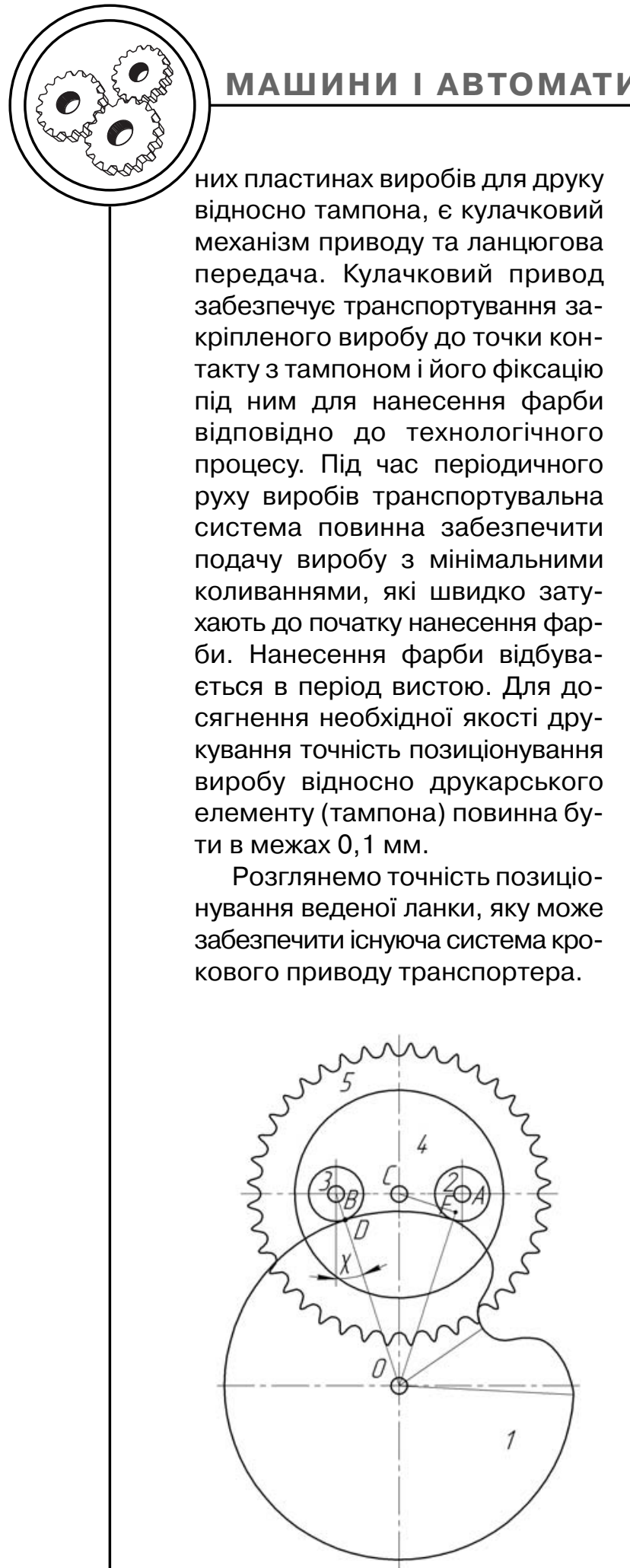

Рис. 2. Схема крокового механізму приводу транспортувальної системи

На рис. 2 представлена схема кулачкового механізму періодичного повороту, яка складається 3 кулачка 1 , роликів 2 і 3 та дискового коромисла 4. На валу, на якому встановлено дискове коромисло 4 розміщується приводна зірка ланцюгової передачі 5.

Розглянемо первинні похибки механізму - похибки профілю кулачка $\Delta \rho_{1}^{n}$ і роликів $\Delta \rho_{2}^{n}$, $\Delta \rho_{3}^{n}$, визначені по нормалі до поверхні кулака в точці контакту; ексцентриситету кулачка $\Delta_{\mathrm{e} 1}$ і роликів $\Delta_{\mathrm{e} 2}, \Delta_{\mathrm{e} 3}$; перекосу осей елементів у шарнірах O, A, B, C в ланках 1, 2, 3, 4 і корпусі відповідно $\Delta \gamma_{\mathrm{O}}, \Delta \gamma_{\mathrm{O} 1}, \Delta \gamma_{\mathrm{A} 2}, \Delta \gamma_{\mathrm{A} 4}, \Delta \gamma_{\mathrm{C} 0}$, $\Delta \gamma_{\text {C4 }}$; неточностей між кріпленням кулачка і коромислового диску $\Delta \mathrm{l}_{\mathrm{Oc}}$ та роликів $\Delta \mathrm{I}_{23}$; первинні похибки у шарнірах $\mathrm{O}, \mathrm{A}$, B, C при монтажу $\Delta \mathrm{q}_{10}, \Delta \mathrm{q}_{24}$, $\Delta \mathrm{q}_{34}, \Delta \mathrm{q}_{40}$. Крім того, існує похибка $\Delta \mathrm{a}_{1}$ положення встановлення ведучого кулака 1 відносно ведучого валу, яка впливатиме в крайніх положеннях рівнорадіусної ділянки профілю, оскільки замикання відбувається по ділянці профілю з постійним радіусом. Ланцюгова передача має свої особливості побудови і її вплив на якість друку є об'єктом окремого дослідження. При використанні додаткових фіксуючих пристроїв при транспортуванні друкованих виробів впливом похибок ланцюгової передачі можна знехтувати.

Для визначення впливу кулачкового приводу повороту приймемо жорстким зв'язок між зіркою ланцюгової передачі і елементом кріплення виробу. Внаслідок притирання шарнірів 
ланок під час роботи кулачкових механізмів похибкою перекосів осей елементів шарнірів, яка при дослідженні не перебільшувала меж $1 \%$, можна знехтувати. Похибка, яку створює перекіс зірки ланцюгової передачі, також знаходиться в межах $1 \%$, тому нею також можна знехтувати.

Для визначення похибки положення кулачкового механізму приймаємо, що всі сили, які діють у системі, будуть розглядатися в площині, паралельній площині pyxy.

Похибка положення коромисла внаслідок похибок профілю кулачка і роликів, визначається:

$$
\begin{aligned}
& \Delta \varphi_{\rho 12}=\frac{\Delta \rho_{1}^{n}+\Delta \rho_{2}^{n}}{C F}, \\
& \Delta \varphi_{\rho 13}=\frac{\Delta \rho_{1}^{n}+\Delta \rho_{3}^{n}}{C F},
\end{aligned}
$$

Величина CF дорівнює:

$$
\mathrm{CF}=\frac{\mathrm{AB}}{2} \cos \chi,
$$

де $\chi$ - кут між нормаллю до поверхні кулака і базою механізму.

Похибки профілю кулачка $\Delta \rho_{1}$ та роликів $\Delta \rho_{2}^{n}$ визначаються за допомогою обміру реальних радіусів кулачка та роликів. А оскільки в нашому випадку ролик знаходиться на нормалі до профілю кулака, то похибки $\Delta \rho_{1}=\Delta \rho_{1}^{n}$.

Що стосується похибок $\Delta \rho_{2}^{n}$ і $\Delta \rho_{3}^{n}$ поверхні роликів 2 і 3 , то вони рівні помилці величини радіусу $r_{2}$ i $r_{3}$ роликів, а похибка $\Delta \rho_{3}^{n}$ зменшує похибку:

$$
\Delta \rho_{2}^{n}=\Delta r_{2} \text { i } \Delta \rho_{3}^{n}=\Delta r_{3}
$$

Таким чином

$$
\begin{aligned}
& \Delta \varphi_{\rho 12}=\frac{\Delta \rho_{1}+\Delta r_{2}}{C F}, \\
& \Delta \varphi_{\rho 13}=\frac{\Delta \rho_{1}-\Delta r_{3}}{C F} .
\end{aligned}
$$

Похибки положення коромисла внаслідок ексцентриситету кулачка і роликів знаходимо за формулою:

$$
\begin{aligned}
\Delta \varphi_{\mathrm{e} 12} & =\frac{\cos \psi_{\mathrm{e} 1} \Delta_{\mathrm{e} 1}-\cos \psi_{\mathrm{e} 2} \Delta_{\mathrm{e} 2}}{\mathrm{CF}}, \\
\Delta \varphi_{\mathrm{e} 13} & =\frac{\cos \psi_{\mathrm{e} 1} \Delta_{\mathrm{e} 1}-\cos \psi_{\mathrm{e} 3} \Delta_{\mathrm{e} 3}}{\mathrm{CF}}
\end{aligned}
$$

де $\psi_{\mathrm{e} 1}, \psi_{\mathrm{e} 2}$ и $\psi_{\mathrm{e} 3}-$ кути між напрямом ексцентриситету і нормаллю профілю кулака в точці контакту.

Зазори в шарнірах О і С є причиною додаткових переміщень ланки 4 відносно ланки 1, а зазори в шарнірах A і B - причиною додаткового повороту ланки 4 відносно шарніра С. Позначимо через $\psi_{\text {sk }}$ кут між нормаллю до поверхонь кулачка і роликів та напрямом відповідного переміщення в шарнірі, яке позначимо відповідно як переміщення першого елементу шарніру з номером s відносно другого елементу з номером k.

Загальна похибка положення коромисла внаслідок зазорів у всіх шарнірах дорівнює: 


$$
\Delta \varphi_{\text {заз }}=\frac{1}{\mathrm{CF}}\left(\begin{array}{c}
-\cos \psi_{10} \Delta \mathrm{q}_{10}- \\
-\cos \psi_{40} \Delta \mathrm{q}_{40}- \\
-\frac{\cos \psi_{24} \Delta \mathrm{q}_{24}}{2}+ \\
+\frac{\cos \psi_{34} \Delta \mathrm{q}_{34}}{2}
\end{array}\right) .
$$

Для визначення похибки положення коромисла внаслідок похибки базової відстані ОС, приймаємо, що шарнір С жорстко закріплений, а кулак переміщається на відстань похибки $\Delta \mathrm{I}_{\mathrm{OC}}$ в шарнірах О і С. Точка контакту D також матиме переміщення $\Delta \mathrm{l}_{\mathrm{OC}}$, яке розкладається по нормалі і дотичної до поверхні кулачка. Величина похибки визначається:

$$
\begin{aligned}
& \Delta \varphi_{\mathrm{OC}}=\frac{\cos \left(\frac{\pi}{2}+\chi\right) \Delta \mathrm{I}_{\mathrm{OC}}}{\mathrm{CF}}= \\
& =\frac{-\sin \chi \Delta \mathrm{l}_{\mathrm{OC}}}{\mathrm{CF}} .
\end{aligned}
$$

Аналогічно знаходимо похибку положення коромисла $\Delta \mathrm{l}_{23}$ внаслідок похибки довжини AB. Проектуємо це переміщення на нормаль і дотичну до поверхні кулака в точці контакту, використовуючи для цього кут між СВ і нормаллю, і отримуємо:

$$
\begin{aligned}
& \Delta \varphi_{23}=\frac{-\cos \left(\frac{\pi}{2}-\chi\right)}{\mathrm{CF}} \Delta \mathrm{I}_{23}= \\
& =\frac{-\sin \chi}{\mathrm{CF}} \Delta \mathrm{I}_{23} .
\end{aligned}
$$

Таким чином була отримана формула похибки положення веденої ланки кулачкового механізму з врахуванням окремих складових похибок, яка з врахуванням напрямку дії похибок визначається:

$$
\Delta \varphi_{k m}=\frac{2}{A B \cos \chi}\left[\begin{array}{c} 
\\
\left(\Delta p_{1}+\Delta r_{2}\right)+\left(\Delta \rho_{1}-\Delta r_{3}\right)+ \\
+\left(\cos \psi_{e 1} \Delta_{e 1}-\cos \psi_{e 2} \Delta_{e 2}\right)+ \\
+\left(\cos \psi_{e 1} \Delta_{e 1}-\cos \psi_{e 3} \Delta_{e 3}\right)+ \\
-\cos \psi_{10} \Delta q_{10}-\cos \psi_{40} \Delta q_{40}- \\
-\frac{\cos \psi_{24} \Delta_{24}}{2}+\frac{\cos \psi_{34} \Delta q_{34}}{2} \\
+\left(-\sin \chi \Delta \Delta_{0 \mathrm{C}}\right)+\left((-\sin \chi) \Delta \Delta_{23}\right)
\end{array}\right]+
$$

А похибка положення виробу відносно друкарських елементів:

$$
\Delta \varphi=r_{\text {zir }} \cdot \tan \Delta \varphi_{\mathrm{km}}+\Delta_{\mathrm{e} 3}
$$

Наведені залежності були використані при проведенні розрахунків похибки положення експериментального крокового ланцюгового транспортера ВШС-254 з приводом від кулачкового механізму з базою - 300 мм, відстанню між роликами - 306 мм, кутом повороту коромислового диску - 180 град. Отримана загальна похибка положення склала $\Delta \varphi=0,053$ мм, що доказує правильність отриманих аналітичних залежностей і можливість визначення похибок положення веденої ланки 3 врахуванням похибок профілю кулачка і роликів, ексцентриситету кулачка і роликів, зазорів у шарнірах, розташування головного і веденого валів, а також технологічних похибок виготовлення коромислового диску тощо.

\section{Висновки}

Запропонована методика аналізу і дослідження крокового кулачкового механізму приводу дозволяє визначати похибки положення системи транспортування і, відповідно, встановлення виробу відносно друкарського елементу з врахуванням конструктивних характеристик систе- 
ми. Проведений аналіз дозволив виявити вузли і елементи приводу, які потребують підвищеної уваги при проектуванні та під час виготовлення, а також звузити коло параметрів, вплив яких суттєво погіршує характеристики приводу, основними з яких є неточності відстані між роликами і профілем кулачка, а також неточності встановлення роликів на коромисловому диску.
3 використанням запропонованої методики був проведений аналіз вузла приводу існуючої транспортувальної системи тамподрукарської машини ТДМ-300, були визначені її основні недоліки і запропонована нова схема транспортувальної крокової системи з заданою точністю позиціонування опорних пластин відносно друкарського елементу [4].

1. Бруевич Н. Г. Точность механизмов / Н. Г. Бруевич. - М. : Гостехиздат, 1946. - 352 с. 2. Калашников Н. А. Точность в машиностроении и ее законы / Н. А. Калашников. - М. : Машгиз, 1950. - 148 с. 3. Середа В. Т. Точність механізмів / В. Т. Середа. - Київ : Вища школа, 1973. - 135 с. 4. Пат. 32250 України, МПК F16H 25/00. Пристрій для отримання періодичного обертального руху веденої ланки / Петрук А. І., Гриценко Д. С., Моргун О. Я. (Україна). - Заявл. 26.12.2007; Опубл. 12.05.2008, Бюл. № 9.

Рецензент - А. І. Іванко, К.т.н., доцент, НТУУ «КПІ» 